\title{
Stability of Cabazitaxel Solution after Dilution in Normal Saline and Stored in Glass
}

\author{
Espinosa Bosch María ${ }^{1 \star}$, Sánchez Rojas Fuensanta², Bosch Ojeda Catalina² \\ 1'Department of Pharmacy, Regional University Hospital of Málaga, Spain \\ ${ }^{2}$ Department of Analytical Chemistry, Faculty of Sciences, University of Málaga, 29071 Málaga, Spain
}

\begin{abstract}
Objective: To evaluate the stability of cabazitaxel diluted in $0.9 \%$ sodium chloride (NS) and stored in glass. Methods: A reverse-phase stability-indicating liquid chromatographic method was developed and validated before the study. The commercially available product was prepared according to the manufacturer's instructions, and further diluted in NS to obtain concentrations of $0.120 \mathrm{mg} / \mathrm{mL}$ and $0.240 \mathrm{mg} / \mathrm{mL}$ cabazitaxel and stored in glass under refrigeration and at $25^{\circ} \mathrm{C}$, all of them protected from light. The concentration of cabazitaxel was evaluated over a period of 21 days. Results: Physical stability: The visual inspection of the stored samples to $25^{\circ} \mathrm{C}(0.120 \mathrm{mg} / \mathrm{mL}$ and $0.240 \mathrm{mg} / \mathrm{mL})$ indicated appearance of a white precipitate in both cases on the day 2 of study. In the case of the refrigerated samples, a similar precipitate appears on the day 6 of the study for the $0.240 \mathrm{mg} / \mathrm{mL}$ concentration and on the day 21 for $0.120 \mathrm{mg} / \mathrm{mL}$ concentration. Chemical stability: The samples that stay physically stable have been evaluated by HPLC method obtaining in all determinations a remaining percentage $>95 \%$. Solutions of cabazitaxel were subjected to a forced degradation analysis. Conclusion: Solutions of cabazitaxel $0.120 \mathrm{mg} / \mathrm{mL}$ prepared in NS and stored in glass retained more than $95 \%$ of the initial drug concentration when stored for one day at $25^{\circ} \mathrm{C}$ and for twenty days at $4^{\circ} \mathrm{C}$. Solutions of cabazitaxel 0.240 $\mathrm{mg} / \mathrm{mL}$ prepared in the same conditions retained more than $95 \%$ of the initial drug concentration when stored for one day at $25^{\circ} \mathrm{C}$ and for two days at $4^{\circ} \mathrm{C}$.
\end{abstract}

Key words: Cabazitaxel, Jevtana, Stability, HPLC, Cytotoxic.

\section{INTRODUCTION}

Cabazitaxel is an antineoplastic agent that disrupts the micro tubular network of cells. It is indicated for men with hormone refractory metastatic prostate cancer previously treated with a docetaxel-containing regimen. ${ }^{1}$

As other members of its drug class, cabazitaxel has poor aqueous solubility. Due to its poor water solubility, cabazitaxel has been formulated in polysorbate 80 (Figure 1).

The current parenteral formulation of cabazitaxel (Jevtana $\left.{ }^{\circledR}\right)$ is supplied as a clear viscous, yellow solution containing $40 \mathrm{mg} / \mathrm{mL}$ of cabazitaxel in polysorbate 80 . Jevtana ${ }^{\circledR}$ injection concentrate vials contain $60 \mathrm{mg}$ of cabazitaxel and are prepacked with a diluent vial containing a $96 \%$ solution of ethanol in water. It is crucial to reconstitute the injection concentrate with the complete content of the diluent vial to ensure a concentration of $10 \mathrm{mg} / \mathrm{mL}$ cabazitaxel in the resulting premix solutions. To compensate for loss of premix solution, due to foaming and adhesion to the walls of the vial both the injection concentrate and the diluent vial are overfilled. After reconstitution the premix solutions should be further diluted in $0.9 \%$ sodium chloride or $5 \%$ dextrose to a final concentration in a range of 0.100 to $0.260 \mathrm{mg} / \mathrm{mL}$ of cabazitaxel. Manufacturer stability data indicates that the reconstituted premix solutions are stable for 1 hour at room temperature and up to 24 hours under refrigeration, and diluted infusion solutions are stable for 8 hours at room temperature and up to 48 hours under refrigeration.
Submission Date : 30-09-2014 Revision Date : :09-12-2014 Accepted Date :23-12-2014

DOI:10.5530/jper.49.1.6 Correspondence Address Mr. María Espinosa Bosch Department of Pharmacy, Regional University Hospital of Málaga, Spain

E mail: maria.espinosa. sspa@juntadeandalucia.es

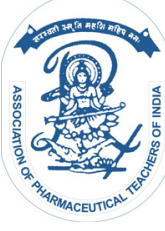

www.ijper.org 


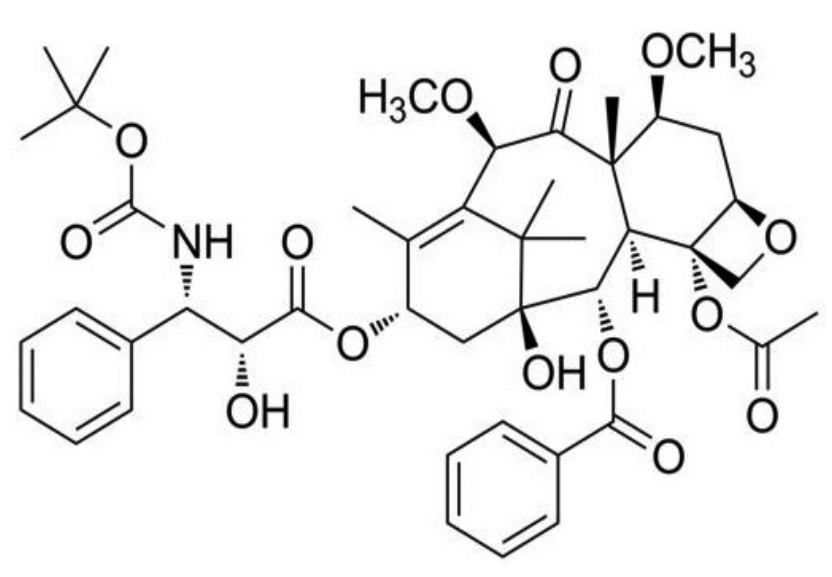

Figure 1: Chemical structure of cabazitaxel

Liquid-chromatographic-tandem mass spectrometric (LC-MS/MS) methods to measure cabazitaxel plasma concentration have been described. ${ }^{2,3}$ but no method has been published about the stability of cabazitaxel in infusion for solution.

The purpose of this study was to determine the stability of cabazitaxel over prolonged periods. Tests were performed on the reconstituted injection concentrate after dilution in $0.9 \%$ sodium chloride at two different concentrations, and stored in glass at room temperature and under refrigeration. Concentrations of diluted cabazitaxel infusion solutions $(0.120 \mathrm{mg} / \mathrm{mL}, 0.240 \mathrm{mg} /$ $\mathrm{mL}$ cabazitaxel) were selected in accordance with the product information. Chemical stability was determined by using a stability-indicating high-performance-liquid chromatographic (HPLC) assay with ultraviolet detection. Physical stability was determined by visual inspection. The results can be used to assign a proper shelf life. ${ }^{4-7}$

\section{MATERIALS AND METHODS}

Cabazitaxel is commercialized by Sanofi-Aventis Groupe in Europe under the trade name Jevtana and by SanofiAventis US in the USA under the trade name Jevtana Kit. Each vial of Jevtana injection concentrate was aseptically reconstituted with the complete content of the diluent vial. The resulting premix solutions contained $10 \mathrm{mg} / \mathrm{mL}$ of cabazitaxel. The premix solution was diluted in $\mathrm{NaCl} 0.9 \%$ to obtain a concentration of 0.3 $\mathrm{mg} / \mathrm{mL}$ of cabazitaxel. Further dilutions were prepared in the same solvent to obtain four samples $(2 \times 0.120$ and $2 \times 0.240 \mathrm{mg} / \mathrm{mL}$, respectively) and five standards of different concentrations $(0.060,0.120,0.180,0.240$ and $0.300 \mathrm{mg} / \mathrm{mL}$ ). The samples were stored in glass at controlled room temperature $\left(25^{\circ} \mathrm{C}\right.$, bacteriological and culture oven with temperature and time regulation and digital reading, Selecta (INCUDIGIT 19L 2001246) and under refrigeration $\left(4^{\circ} \mathrm{C}\right)$ protected from the light.
The standards were divided into different aliquot parts, stored in eppendorf tubes and frozen until each analysis day.

HPLC-grade acetonitrile was obtained from SigmaAldrich. Sterile $\mathrm{NaCl} 0.9$ \% Fresenius Kabi was used as diluent. Deionised water was used throughout. Other chemical were of analytical grade.

\section{Physical stability study}

The physical stability of the samples was assessed by visual examination during all studied days for colour change and/or precipitation.

\section{Chemical stability study}

Cabazitaxel concentrations were determined by a stability-indicating HPLC method. HPLC analysis was performed at room temperature $\left(\sim 25^{\circ} \mathrm{C}\right)$ using an Agilent Technologies, model LC 1220 Infinity including isocratic pump (maximum pressure 600 bar), manual injector valve and detector with variable wavelength (working wavelength at $235 \mathrm{~nm}$ ). The signal from the detector was recorder and integrated with a PC HP Pro 3010 Desktop VN934EA; a Zorbax Eclipse XDB-C18, 4.6 × $250 \mathrm{~mm}$, $(5 \mu \mathrm{m})$ column was employed. The mobile phase consisted of acetonitrile: water $(80: 20, \mathrm{v} / \mathrm{v})$ delivered at flow rate of $1.5 \mathrm{~mL} / \mathrm{min}$. The sample injection volume was 20 $\mu \mathrm{L}$, and triplicate injections were performed for every sample. The retention time for cabazitaxel was 2.85 minutes.

The initial concentration of cabazitaxel was defined as $100 \%$, and subsequent sample concentrations were expressed as a percentage of the initial concentration. Stability of the drug was defined as retention of at least $95 \%$ of the initial drug concentration.

\section{Forced degradation analysis}

Forced degradation is a degradation of new drug substance and drug product at conditions more severe than accelerated conditions. It is required to demonstrate specificity of stability indicating methods and also provide saninsight into degradation path ways and degradation products of the drug substance. ${ }^{8,9}$

Six different studies were carried out for this purpose over cabazitaxel solution stored under refrigeration: acid, base, heat, UV light, hydrogen peroxide and sodium hypochlorite.

\section{RESULTS AND DISCUSSION}

\section{Physical stability}

All solutions were initially clear and colourless and remained so for the duration of the study. Some sam- 


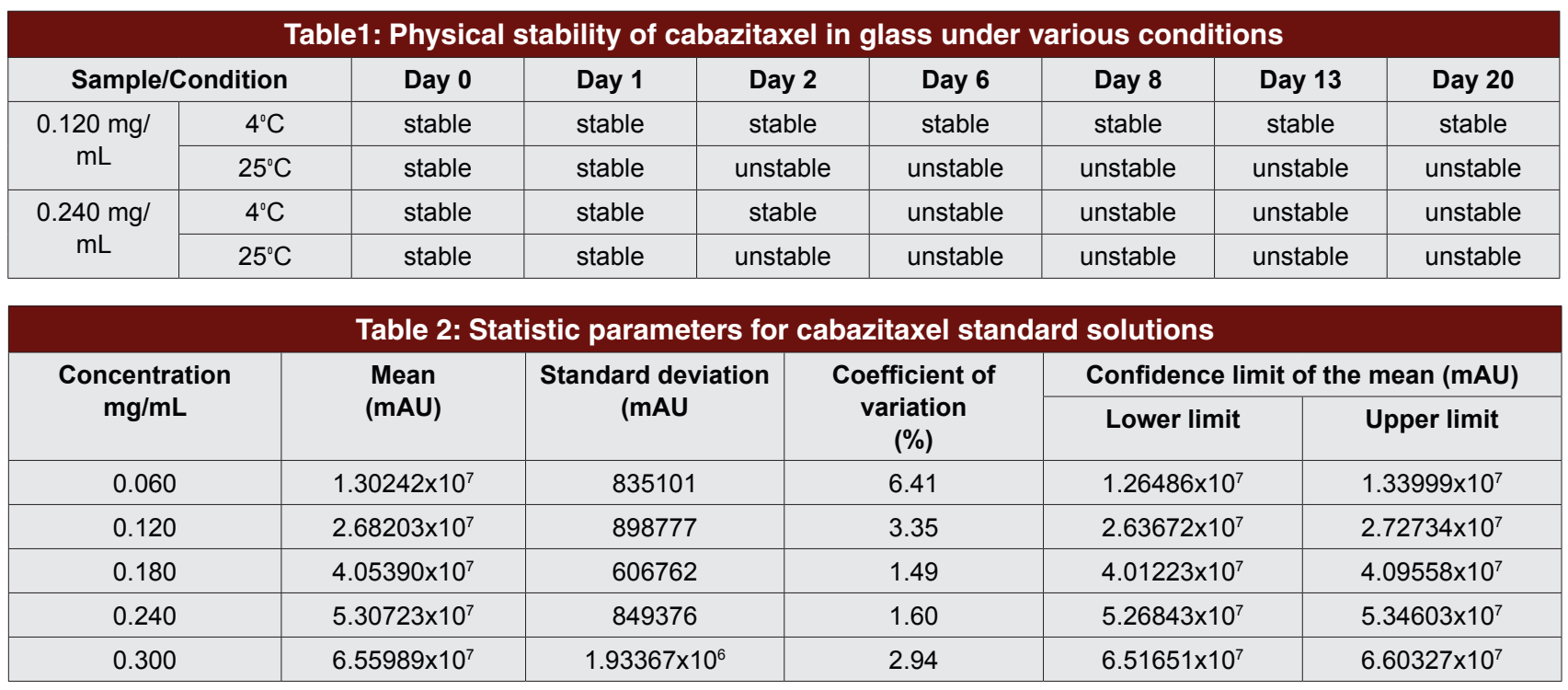

ples are physically unstable due to the appearance of a white precipitate depending of the concentration of solutions and the storage temperature (Table 1).

\section{Chemical stability}

All the physically stable solutions were chromatographied. The experimental data were processed making use of the Stat graphics Centurion XVI program. The linearity of the method was evaluated at 5 concentration levels injected by triplicate varying from 0.060 $\mathrm{mg} / \mathrm{mL}$ to $0.300 \mathrm{mg} / \mathrm{mL}$. The calibration curve constructed from plots of peak area versus concentration of cabazitaxel reference standard was linear, the slope was 219002, the intercept 390520, the correlation coefficient $\left(R^{2}\right)$ 0.9994, and the standard error of slope was 3142. Assay precision was determined with the signals obtained for cabazitaxel standard solutions; the results are showed in Table 2.

On the other hand, Table 3 presents the results obtained of a multiple range test carried out with the signals corresponding to the standards and the analysed samples. This test applies a multiple comparison procedure to determine which means are significantly different from others. The lower half of the table shows differences estimated between each pair of means. The asterisk located next to 30 pairs indicates that these pairs show statistically significant differences with the $95.0 \%$ confidence level. At the top of the table, we have identified 5 homogeneous groups according to the alignment of the X's in columns. There are no statistically significant differences between those levels that share a same column of X's.

During the study period, the concentration in all study sample retained at least $97 \%$ of the initial concentration of cabazitaxel.

\section{Accelerated degradation analysis}

The subsequent studies were made over cabazitaxel solution stored at $4{ }^{\circ} \mathrm{C}$.

pH study. To eight aliquots of $500 \mu \mathrm{L}$ of $0.120 \mathrm{mg} / \mathrm{mL}$ of cabazitaxel were added different amounts of $\mathrm{HCl}$ (0.1 $\mathrm{M}$ and $1 \mathrm{M})(100,250,500$ and $1000 \mu \mathrm{L}$ of both concentration). In all cases, the chromatograms showed two peaks, at 1.40 min corresponding to a degradation product and at $2.85 \mathrm{~min}$ corresponding to cabazitaxel.

The same manner, to eight aliquots of $500 \mu \mathrm{L}$ of 0.120 $\mathrm{mg} / \mathrm{mL}$ of cabazitaxel was added different amounts of $\mathrm{NaOH}(0.1 \mathrm{M}$ and $1 \mathrm{M})(100,250,500$ and $1000 \mu \mathrm{L}$ of both concentration). The results indicated that after 20 minutes storage in $\mathrm{NaOH} 1 \mathrm{M}$ for all volumes added or after different times (between 20 - 60 minutes) depending of volume added of $\mathrm{NaOH} 0.1 \mathrm{M}$ only a trace of cabazitaxel was detected in the chromatograms. The higher difference observed in these chromatograms were the presence of diverse peaks corresponding to degradation products (at 1.40 and $1.97 \mathrm{~min}$ ).

Heat study. Three samples of $0.120 \mathrm{mg} / \mathrm{mL}$ of cabazitaxel were heat at different temperatures $\left(40^{\circ} \mathrm{C}, 60^{\circ} \mathrm{C}\right.$, $80^{\circ} \mathrm{C}$ ) during different times (from 5 to 60 minutes). No significant changes were observed in the chromatograms in all cases.

UV light. A sample of $0.120 \mathrm{mg} / \mathrm{mL}$ of cabazitaxel was subject to UV irradiation during one day. No significant changes were observed visually and in the chromatograms.

Hydrogen peroxide. To twelve aliquots of $500 \mu \mathrm{L}$ of 0.120 $\mathrm{mg} / \mathrm{mL}$ of cabazitaxel were added different amounts $(100,250,500$ and $1000 \mu \mathrm{L})$ of $\mathrm{H}_{2} \mathrm{O}_{2}$ of different concentrations (0.03, 0.3 and $3 \%$ ). Degradation of cabazitaxel occurs quickly with $3 \% \mathrm{H}_{2} \mathrm{O}_{2}$ simultaneously appear the signal corresponding to the degradation 


\section{Table 3: Multiple range test}

\begin{tabular}{|c|c|c|c|}
\hline $\begin{array}{c}\text { Standards and samples } \\
(\mathrm{mg} / \mathrm{mL})\end{array}$ & $\operatorname{Mean}(\mathrm{mAU})$ & Homogeneous groups & \\
\hline 0.060 & $1,30242 \times 10^{7}$ & $x$ & \\
\hline 0.120 & $2,68203 \times 10^{7}$ & $x$ & \\
\hline $0.120\left(25^{\circ} \mathrm{C}\right)$ & $2,66072 \times 10^{7}$ & $x$ & \\
\hline $0.120\left(4^{\circ} \mathrm{C}\right)$ & $2,61542 \times 10^{7}$ & $x$ & \\
\hline 0.180 & $4,05390 \times 10^{7}$ & $x$ & \\
\hline 0.240 & $5,30723 \times 10^{7}$ & $x$ & \\
\hline $0.240\left(25^{\circ} \mathrm{C}\right)$ & $5,31080 \times 10^{7}$ & $x$ & \\
\hline $0.240\left(4^{\circ} \mathrm{C}\right)$ & $5,31302 \times 10^{7}$ & $x$ & \\
\hline 0.300 & $6,55989 \times 10^{7}$ & $x$ & \\
\hline Contrast & Sig. & Difference & \pm Limits \\
\hline $0.060-0.120$ & * & $-1,3796 \times 10^{7}$ & 832398 \\
\hline $0.060-0.180$ & * & $-2,75148 \times 10^{7}$ & 793547 \\
\hline $0.060-0.240$ & * & $-4,00481 \times 10^{7}$ & 763801 \\
\hline $0.060-0.300$ & * & $-5,25747 \times 10^{7}$ & 811584 \\
\hline $0.060-0.120\left(25^{\circ} \mathrm{C}\right)$ & * & $-1,35829 \times 10^{7}$ & $1,33709 \times 10^{6}$ \\
\hline $0.060-0.120\left(4^{\circ} \mathrm{C}\right)$ & * & $-1,31299 \times 10^{7}$ & 751381 \\
\hline $0.060-0.240\left(25^{\circ}\right)$ & * & $-4,00838 \times 107$ & $1,33709 \times 10^{6}$ \\
\hline $0.060-0.240\left(4^{\circ} \mathrm{C}\right)$ & * & $-4,0106 \times 10^{7}$ & $1,01737 \times 10^{6}$ \\
\hline $0.120-0.180$ & * & $-1,37188 \times 10^{7}$ & 870648 \\
\hline $0.120-0.240$ & * & $-2,62521 \times 10^{7}$ & 843626 \\
\hline $0.120-0.300$ & * & $-3,87786 \times 10^{7}$ & 887120 \\
\hline $0.120-0.120\left(25^{\circ} \mathrm{C}\right)$ & - & 213074 & $1,38424 \times 10^{6}$ \\
\hline $0.120-0.120\left(4^{\circ} \mathrm{C}\right)$ & - & 666096 & 832398 \\
\hline $0.120-0.240\left(25^{\circ} \mathrm{C}\right)$ & * & $-2,62877 \times 10^{7}$ & $1,38424 \times 10^{6}$ \\
\hline $0.120-0.240\left(4^{\circ} \mathrm{C}\right)$ & * & $-2,631 \times 107$ & $1,07859 \times 10^{6}$ \\
\hline $0.180-0.240$ & * & $-1,25333 \times 107$ & 805317 \\
\hline $0.180-0.300$ & * & $-2,50599 \times 10^{7}$ & 850771 \\
\hline $0.180-0.120\left(25^{\circ} \mathrm{C}\right)$ & * & $1,39319 \times 10^{7}$ & $1,36123 \times 10^{6}$ \\
\hline $0.180-0.120\left(4^{\circ} \mathrm{C}\right)$ & * & $1,43849 \times 10^{7}$ & 793547 \\
\hline $0.180-0.240\left(25^{\circ} \mathrm{C}\right)$ & * & $-1,2569 \times 10^{7}$ & $1,36123 \times 10^{6}$ \\
\hline $0.180-0.240\left(4^{\circ} \mathrm{C}\right)$ & * & $-1,25912 \times 10^{7}$ & $1,0489 \times 10^{6}$ \\
\hline $0.240-0.300$ & * & $-1,25266 \times 10^{7}$ & 823097 \\
\hline $0.240-0.120\left(25^{\circ} \mathrm{C}\right)$ & * & $2,64651 \times 10^{7}$ & $1,34411 \times 10^{6}$ \\
\hline $0.240-0.120\left(4^{\circ} \mathrm{C}\right)$ & * & $2,69182 \times 10^{7}$ & 763801 \\
\hline $0.240-0.240\left(25^{\circ} \mathrm{C}\right)$ & - & -35690 & $1,34411 \times 10^{6}$ \\
\hline $0.240-0.240\left(4^{\circ} \mathrm{C}\right)$ & - & -57905 & $1,02658 \times 10^{6}$ \\
\hline $0.300-0.120\left(25^{\circ} \mathrm{C}\right)$ & * & $3,89917 \times 10^{7}$ & $1,37183 \times 10^{6}$ \\
\hline $0.300-0.120\left(4^{\circ} \mathrm{C}\right)$ & * & $3,94447 \times 10^{7}$ & 811584 \\
\hline $0.300-0.240\left(25^{\circ} \mathrm{C}\right)$ & * & $1,24909 \times 10^{7}$ & $1,37183 \times 10^{6}$ \\
\hline $0.300-0.240\left(4^{\circ} \mathrm{C}\right)$ & * & $1,24687 \times 10^{7}$ & $1,06261 \times 10^{6}$ \\
\hline $0.120\left(25^{\circ} \mathrm{C}\right)-0.120\left(4^{\circ} \mathrm{C}\right)$ & - & 453022 & $1,33709 \times 10^{6}$ \\
\hline $0.120\left(25^{\circ} \mathrm{C}\right)-0.240\left(25^{\circ} \mathrm{C}\right)$ & * & $-2,65008 \times 10^{7}$ & $1,73524 \times 10^{6}$ \\
\hline $0.120\left(25^{\circ} \mathrm{C}\right)-0.240\left(4^{\circ} \mathrm{C}\right)$ & * & $-2,6523 \times 10^{7}$ & $1,50276 \times 10^{6}$ \\
\hline $0.120\left(4^{\circ} \mathrm{C}\right)-0.240\left(25^{\circ} \mathrm{C}\right)$ & * & $-2,69538 \times 10^{7}$ & $1,33709 \times 10^{6}$ \\
\hline $0.120\left(4^{\circ} \mathrm{C}\right)-0.240\left(4^{\circ} \mathrm{C}\right)$ & * & $-2,69761 \times 10^{7}$ & $1,01737 \times 10^{6}$ \\
\hline $0.240\left(25^{\circ} \mathrm{C}\right)-0.240\left(4^{\circ} \mathrm{C}\right)$ & - & -22215 & $1,50276 \times 10^{6}$ \\
\hline
\end{tabular}


Table 4: provides stability data of cabazitaxel stored at $4^{\circ} \mathrm{C}$ and $25^{\circ} \mathrm{C}$ in the dark over 20 days, tested at a diluted concentration of 0.120 and $0.240 \mathrm{mg} / \mathrm{mL}$ when physically stable.

Chemical stability of cabazitaxel in glass under various conditions

\begin{tabular}{|c|c|c|c|c|c|c|c|c|}
\hline \multirow[t]{3}{*}{ Day } & \multicolumn{4}{|c|}{$0.120 \mathrm{mg} / \mathrm{mL}$} & \multicolumn{4}{|c|}{$0.240 \mathrm{mg} / \mathrm{mL}$} \\
\hline & \multicolumn{2}{|c|}{$4^{\circ} \mathrm{C}$} & \multicolumn{2}{|c|}{$25^{\circ} \mathrm{C}$} & \multicolumn{2}{|c|}{$4^{\circ} \mathrm{C}$} & \multicolumn{2}{|c|}{$25^{\circ} \mathrm{C}$} \\
\hline & mg/mLtSD* & $\%$ ** & $\mathrm{mg} / \mathrm{mL} \pm \mathrm{SD}^{*}$ & $\%$ ** & $\mathrm{mg} / \mathrm{mL} \pm \mathrm{SD}^{*}$ & $\%$ ** & $\mathrm{mg} / \mathrm{mL} \pm \mathrm{SD}^{*}$ & $\%$ ** \\
\hline 0 & 0.120 & 100 & 0.120 & 100 & 0.240 & 100 & 0.240 & 100 \\
\hline 1 & $0.120 \pm 0.001$ & 100 & $0.120 \pm 0.001$ & 100 & $0.240 \pm 0.001$ & 100 & $0.240 \pm 0.001$ & 100 \\
\hline 2 & $0.120 \pm 0.001$ & 100 & - & - & $0.241 \pm 0.001$ & 100.4 & - & - \\
\hline 6 & $0.118 \pm 0.001$ & 98.3 & - & - & - & - & - & - \\
\hline 8 & $0.117 \pm 0.001$ & 97.5 & - & - & - & - & - & - \\
\hline 13 & $0.122 \pm 0.003$ & 101.7 & - & - & - & - & - & - \\
\hline 20 & $0.121 \pm 0.011$ & 100.8 & - & - & - & - & - & - \\
\hline
\end{tabular}

*mean \pm standard deviation; $\mathrm{n}=3 ; * * \%$ remaining of cabazitaxel.

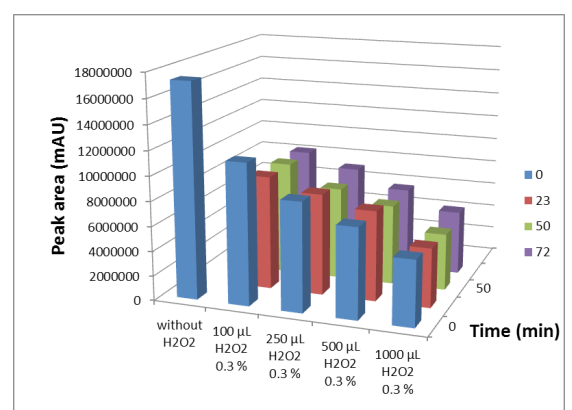

a)

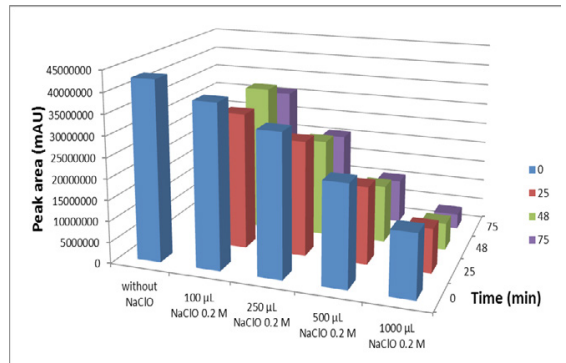

c)

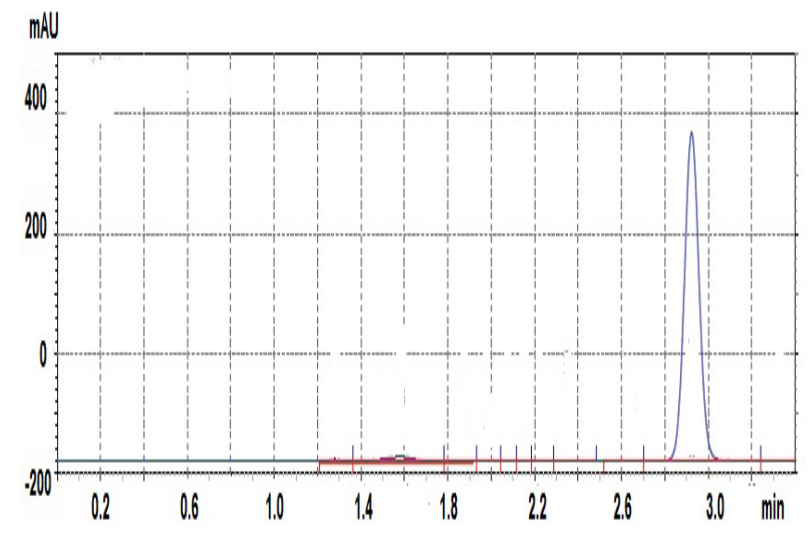

e)

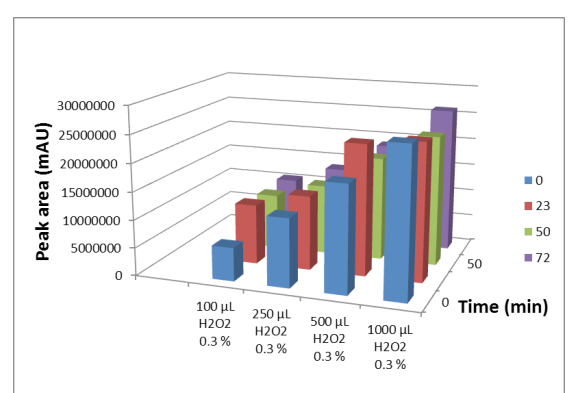

b)

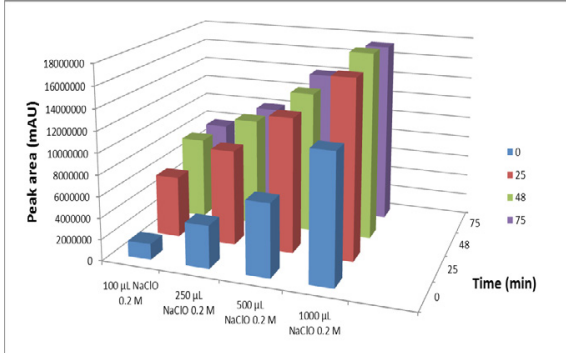

d)

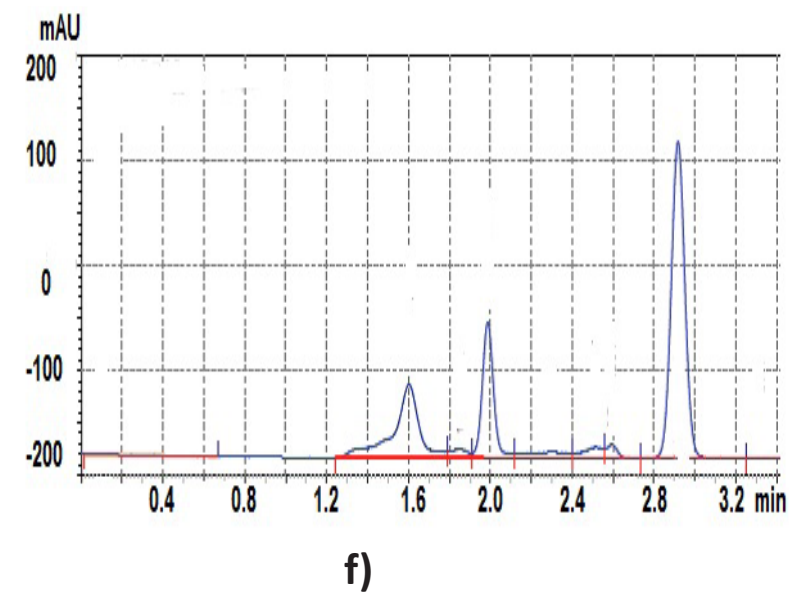

Figure 2. Variation of the cabazitaxel signal with the time for different additions of $\mathrm{H} 2 \mathrm{O} 20.3 \mathrm{M} ; \mathbf{R}_{\mathrm{t}}=\mathbf{2 . 8 5}$ min (a) and degradation product $R_{t}=1.4 \mathrm{~min}(\mathrm{~b})$ Variation of the cabazitaxel signal with the time for different additions of $\mathrm{NaClO} 0.2 \mathrm{M} ; R_{t}=2.85 \mathrm{~min}$ (c) and degradation product $R_{t}=1.4 \mathrm{~min}$ (d). Chromatographic spectra of developed method for pure cabazitaxel (e) and for degraded drug after 75 minutes of forced degradation with $100 \mu \mathrm{I} \mathrm{NaClO} \mathrm{0,2M.}$ 
product $\left(\mathrm{R}_{\mathrm{t}}=1.40 \mathrm{~min}\right)$ which increase very much with the volume of $\mathrm{H}_{2} \mathrm{O}_{2}$ added. Solutions with lower concentration of hydrogen peroxide degrade cabazitaxel more slowly, as can be seen in Figure $2 \mathrm{a}$ at the same time the signal corresponding to degradation product increase as can be seen in Figure 2b.

Sodium hypocblorite. To twelve aliquots of $500 \mu \mathrm{L}$ of 0.120 $\mathrm{mg} / \mathrm{mL}$ of cabazitaxel were added different amounts $(100,250,500$ and $1000 \mu \mathrm{L})$ of $\mathrm{NaClO}$ of different concentrations (0.02, 0.2 and 2 M).Degradation of cabazitaxel occurs quickly with $2 \mathrm{M} \mathrm{NaClO}$ simultaneously appear the signal corresponding to the degradation product $\left(\mathrm{R}_{\mathrm{t}}=1.40 \mathrm{~min}\right)$ which increase very much with the volume of $\mathrm{NaClO}$ added. Solutions with lower concentration of $\mathrm{NaClO}$ degrade cabazitaxel more slowly, as can be seen in Figure $2 \mathrm{c}$ at the same time the signal corresponding to degradation product increase as can be seen in Figure 2d. Also a signal corresponding to other degradation product appears to 1.97 minutes. Chromatographic spectra of developed method for pure cabazitaxel and for degraded drug after 75 minutes of forced degradation with $100 \mu \mathrm{l} \mathrm{NaClO} 0.2 \mathrm{M}$ can be seen in Figure 2e and 2f.

\section{CONCLUSION}

Solutions of cabazitaxel $0.120 \mathrm{mg} / \mathrm{mL}$ prepared in NS and stored in glass retained more than $95 \%$ of the initial drug concentration when stored for one day at $25^{\circ} \mathrm{C}$ and for twenty days at $4^{\circ} \mathrm{C}$. Solutions of cabazitaxel 0.240 $\mathrm{mg} / \mathrm{mL}$ prepared in the same conditions retained more than $95 \%$ of the initial drug concentration when stored for one day at $25^{\circ} \mathrm{C}$ and for two days at $4^{\circ} \mathrm{C}$. Test solutions and storage conditions were selected to observe normal clinical practice. Further investigations to establish the concentration limit for which the stability can be prolonged would enable an extended shelf life to be assigned to prepared infusions. This would then allow inclusion in dose-banding schemes. The method we describe presents enough accuracy and precision for being incorporated in a stability indicating study.

\section{ACKNOWLEDGEMENT}

The authors gratefully acknowledge Junta de Andalucía for supporting this work

\section{REFERENCES}

1. Sanofi-Aventis. Summary of Product Characteristics. Jevtana; April 2014.

2. De Bruijn P, De Graan AJM, Nieuweboer A, et al. Quantification of cabazitaxel in human plasma by liquid chromatography/triple-quadrupole mass spectrometry: A practical solution for non-specific binding. J Pharm Biomed Anal. 2012; 59(1): 117-22.

3. Kort A, Hillebrand MJX, Cirkel GA, et al. Quantification of cabazitaxel, its metabolite docetaxel and the determination of the demethylated metabolites RPR112698 and RPR123142 as docetaxel equivalents in human plasma by liquid chromatography-tandem mass spectrometry. J Chromatog B. 2013; 925:(1): 117-23.

4. Methodological guidelines for stability studies of hospital pharmaceutical preparations. SFPC-GERPAC, Under the aegis of SFPC (French Society of Clinical Pharmacy) and GERPAC (Evaluation and Research Group on Protection in Controlled Atmospher). 1st Edition; October 2013.

5. Trissell LA, Flora KP. Stability studies: five years later. Am J Hosp Pharm. 1988; 45(1): 1569-71.

6. 6. Williams LA, Hastings MB, AllenJr LV. Identifying the criteria of a valid stability study. Int J Pharm Compound. 2009; 13(1): 32-6

7. Maggio RM, Vignaduzzo SE, Kaufman TS. Practical and regulatory considerations for stability-indicating methods for the assay of bulk drugs and drug formulations. Trends Anal Chem. 2013; 49(1): 57-70.

8. Singh $\mathrm{S}$, Junwal M, Modhe $\mathrm{G}$, et al. Forced degradation studies to assess the stability of drugs and products. Trends Anal Chem. 2013; 49(1): 71-88.

9. Blessy M, Patel RD, Prajapati PN, et al. Development of forced degradation and stability indicating studies of drugs-A review. J Pharm Anal. 2014; 4(3): 159-65. 